\title{
$r$ 線照射における5'ーヌクレオチド水溶液の安定性
}

\author{
東洋食品工業短期大学 寺田潤子・秦 圭子・毛利威德・橋田 度・志賀岩雄
}

Effects of $\gamma$-Irradiation on the Stability of 5'-Nucleotides in Solutions

Junko TERADA, Keiko HATA, Takenori MOURI, Wataru HASHIDA and Iwao SHIGA

Toyo Junior College of Food Technology, Kawanishi, Hyogo, Japan

\section{Summary}

5'-IMP and related 5'-nucleotides are potent flavor substances contained in some foods. Sodium salts of 5'-IMP and other 5'-nucleotides were dissolved in distilled water or buffered solution and sealed in glass ampoules under atmosphere. The samples were irradiated with a 5,000 curie cobalt-60 source at the dose rates of $2.3 \times 10^{3}-3.6 \times 10^{5}$ $\mathrm{r} / \mathrm{hr}$ at room temperature.

The residual levels of 5'-IMP irradiated at 1.0 Mrad were 61 and $86 \%$ in distilled water and in buffer of $\mathrm{pH} 7$ (Fig. 2), respectively. The decimal reduction dose at $\mathrm{pH} 7$ was 17.2 Mrad. 5'-IMP was found to be more labile at $\mathrm{pH} 3$ and 5 rather than at $\mathrm{pH} 7$ and 9 (Fig. 3). Irradiation of 5'-IMF led to the splitting of the bond between nucleic base and ribose phosphate, resulting in the increase of hypoxanthine (Table 5 and 6 ).

There is a significant difference between the mode of decomposition affected by heating and by $\gamma$-irradiation. Purine nucleotides are more stable than pyrimidine nucleotides against $\gamma$-irradiation (Table 3 and 4 ), but the formers are more labile than the latters against heating. Existence of sugar is protective against the destruction by $\gamma$-ray (Fig. 5) but is promotive of that by heat.

緒言

柆酸垛よびその成分に対する放射線の影響についてはすでに数々の研究が行われており，光化学的な安 定性扰よひ分解生成物については2.3の総説 ${ }^{1) 〜 3)}$ 亿要約されている。一方食品の放射線処理に関連し 
て細胞の D NA, R NAに対する生理学的な研究も行なわれている。4)

核酸成分の中でる 5 '一ヌクレオチドは食品の呈味成分として重要なるのであるが，食品のて線照射に よってその安定性がどんな影響を受けるかは興味梁いものである。近年魚類にと線を照射した場合のヌク レオチト・関連成分の変化扣上びその風味に対する影響に 2.3 の検討5)ー）が行なわれている。また最近 久保田: 渡辺氏に上って水溶液に抢ける核酸成分の変化について報告された。）

本報においてはまず5'ーヌクレオチド水溶液を対照としてて線照射を行なった場合に，5'一ヌクレ オチドの安定性に対する照射線量, 溶液 $\mathrm{pH}$, 共存食品成分の影響についてしらべ,さらに個々の $5^{\prime}-$ ヌクレオチド相互の安定性の此較㧍よび分解生成物についての検討を行なったので報告する。

夷 験 方 法

\section{I $r$ 線照射設備}

住友原子力工業株式会社宝塚放射線研究所 C $0-60$ 照射夷験室に照射依頼した。

Coー60 線源は約 5.000 キュリー, 線量率は $2.3 \times 10^{3} \sim 3.56 \times 10^{5}$ レントゲン/hr，の範井で あった。

II 供 試 試 料

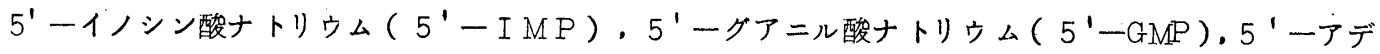
ニル酸ナトリウム $\left(5^{\prime}\right.$-AMP $), 5^{\prime}$ ーシチジル酸ナトリウム $\left(5^{\prime}\right.$ - C MP $)$ 扣よび5'一ウリシル酸 ナトリウム ( $5^{\prime}$-UMP) $)$ は武田薬品工業株式会社より恵与された。

試料溶液の調整

1）水溶液：5'ー・ヌクレオチドを0.2，0.5\%莀度で蒸留水に溶解したもの。

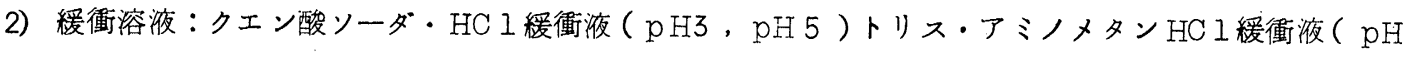
7. $\mathrm{pH} 9$ )に $5^{1}$ ーヌクレオチドを0.2・0.5\%濃度で溶解したものをそれぞれ用いた。

これらの試料溶液を $20 \mathrm{~m} \ell$ 容量の硬質ガラスアンプルに封入して $r$ 線を照射した。

対照としてr線を照射せず冷蔵保存，室温保存の試料をと斿た。

III分析方法

$5^{\prime}$ ーリボヌクレオチドの分析

a) 5'ーヌクレオチドの定量は5'一リボヌクレオチダーゼ( Bull seminal nucleotidase) を用いる中島らの醉素法・また個々のヌクレオチドの分析にはBergkvist法によるDowex $1 \times 8$ を 用いるカラムクロマトグラフイーによった。

b） 5'ーヌクレオチドの分解生成物の確認には飽和硫安・1 M酶酸ソーダ・イソープロパノール（８０：

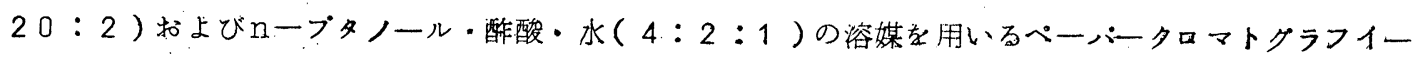
によった。東洋沪紙N6.51 を用いた。なおスポットの確認には紫外線ランプ（253 m 実験結果と考察

\section{I 安定怪に及添す照射線量の影響 ( 水溶液中)}

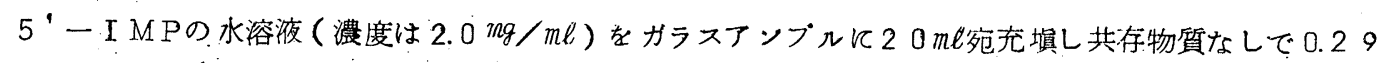
〜27.6 × $10^{6} \mathrm{rad}$ 線を照射した結果は Table 1.のようである。

すなわち。照射線量が高くなるに伴って $\mathrm{pH}$ が低下し色調が黄色儿近すくことが認められ，5・ーIMP 
の残存隼が低下した。なお $5^{`}$-I MPは後述の pH７Ｂuffer飞おける挙動と比較するとBuffer内 よりも不安定であることが認められる。

ここで全線量が一定で単位時間の線量率を異にする場合の $5^{\prime}$ - I M P の安定性を比較吟味した。すな わち. $5^{\prime}$ - I M P を蒸留水で溶解して $2.0 \mathrm{mg} / \mathrm{ml}$ の溶液とし $1.00 \times 10^{6} \mathrm{rad}$ の全線量で線量率が

Table 1. Stability of 5'-IMP irradiated in distilled water

\begin{tabular}{ccc}
\hline $\begin{array}{c}\text { Irradiation } \\
\text { dose } \\
\left(10^{6} \text { rad }\right)\end{array}$ & $\begin{array}{c}\mathrm{pH} \\
\text { after } \\
\text { irradiation }\end{array}$ & $\begin{array}{c}\% \text { 5'-IMP } \\
\text { remaining }\end{array}$ \\
\hline 0 & $(7.32)$ & $(100)$ \\
0.29 & 6.95 & 90.3 \\
0.96 & 6.71 & 64.2 \\
2.88 & 6.62 & 29.9 \\
27.6 & 6.47 & 1.6 \\
\hline
\end{tabular}

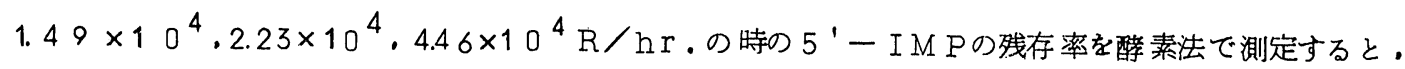
残存率はそれぞれ59.2．61.5，62.4\%であってはぼ定となり，この範囲の線量率では残存率に対

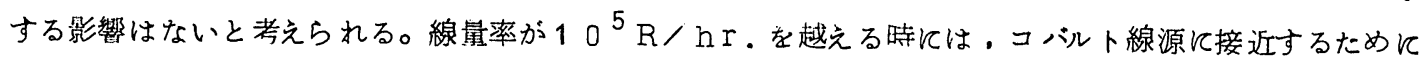
温度の調節や照射の均一化など 2 次的な考虑が必要となるたろう。

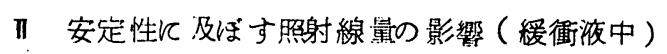

$5^{\prime}$ - I MP・Na ? 標品を $\mathrm{pH} 7$ のトリス・アミノメタン・HCl Buffer( $\left.1 / 20 \mathrm{M}\right) \mathrm{k} 2 \mathrm{mg} / \mathrm{m} \ell$ Table 2. Stability of 5'-IMP irradiated in Tris-buffer ( $\mathrm{pH} 7)$.

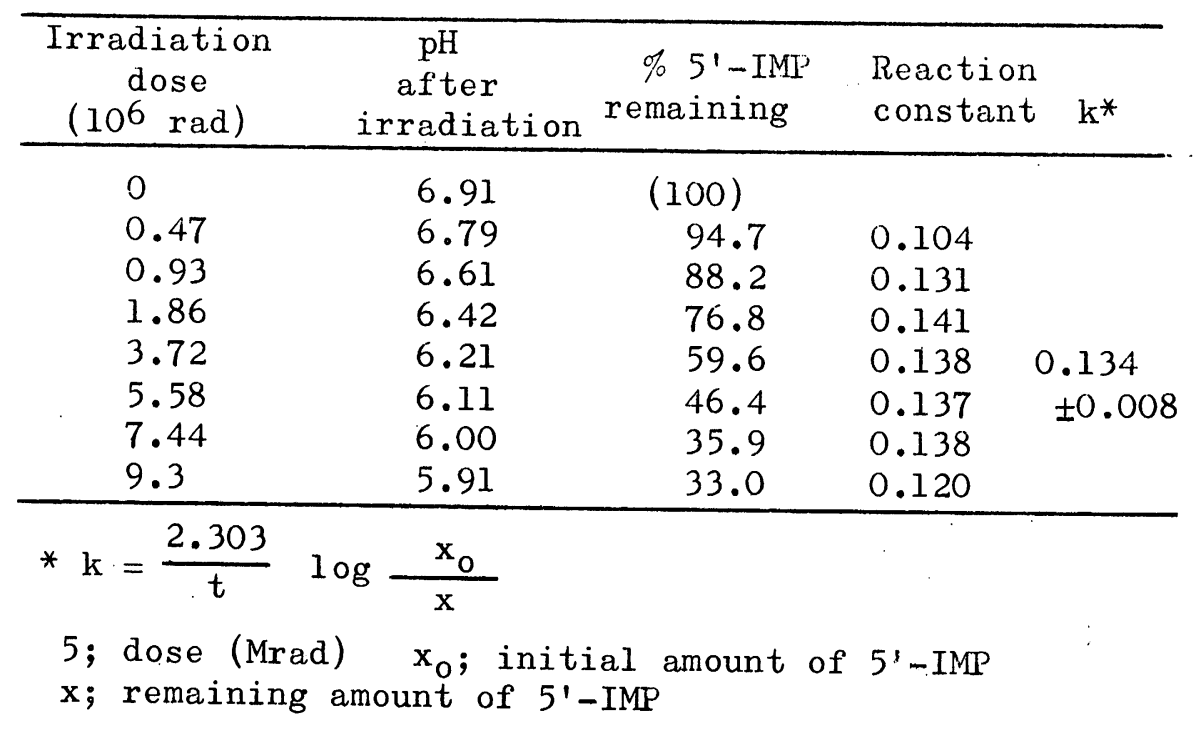


の割合に溶解し，ガラスアンプルに空気の共存下に $20 \mathrm{~m} l$ 宛封入し $r$ 線を照射した。線量率は $2.3 \times 10^{3}$

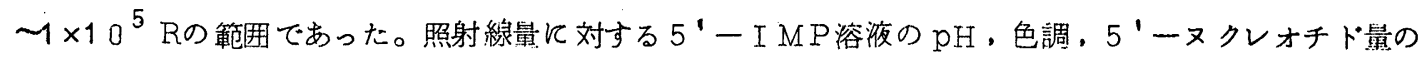
変化を示扵とTable 2 のようである。

すなわち，照射線量が增加するに伴い $\mathrm{pH}$ H酸性側に移行しかつ色調は黄色を带ひるようとなる。この色は後

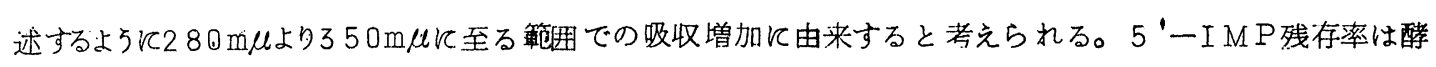
素法による5'ーヌクレオチド量より計算したものである。

同表の $5^{1}$ - I M P 残存率の対数と照射線量の関係図示寸ると，Fig.1.のよ5になりほほ $10^{6} \mathrm{rad}$ から 107 Iadの範囲では直線関係になると認められた。従って5 ' I M P 初濃度をa％(ここでは

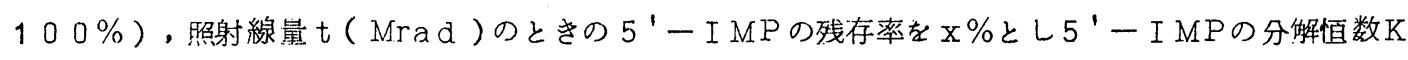
を次式から計算すると $\mathrm{Table} 2$. 亿示すようである。

$$
K=\frac{2.303}{t} \log \frac{a}{x}
$$

分解恒数の平均值は $0.134 \pm 0.008$ であった。そして一定量を90\%分解する照射量すなわら残存率 $10 \%$ 場合のD值は1 7.2 Mradであった。照射した $5^{\prime}$ － I MP溶液の100倍稀釈（pH2.0）の 紫外部吸収曲線はFig.2 亿示寸上ろである。照射線量が増加するに伴って2 $50 \mathrm{~m} \mu$ の吸収が减少し $220 \mathrm{~m} \mu$ および2 $80 \mathrm{~m} \mu \sim 300 \mathrm{~m} \mu$ の吸収が增加することが認められた。なお遠紫外部でも300〜 $350 \mathrm{~m} \mu$ の範囲で吸収が堌加した。

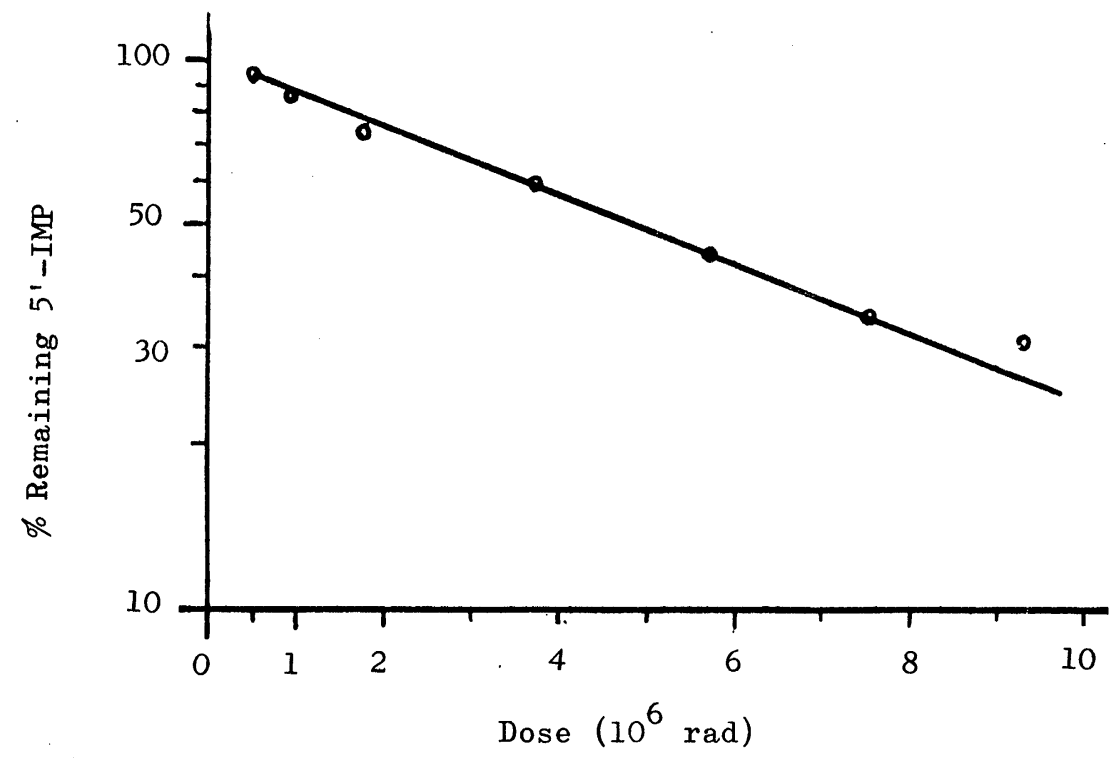

Fig. 1 Relation of remaining 5'-IMP and corresponding irradiation doses in Tris-buffer ( $\mathrm{pH} 7$ ). 


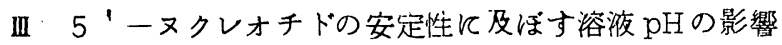

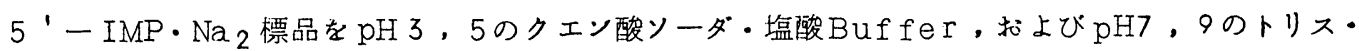
アミノメタン・塩酸Bufferkいずれる $2 \mathrm{mg} / \mathrm{ml}$ の溶液になる上うに溶解しカララスアンプル内にて空気 共存下に $10^{6} \sim 10^{7} \mathrm{rad} r$ 線を照射した結果はFig・3.のようである。

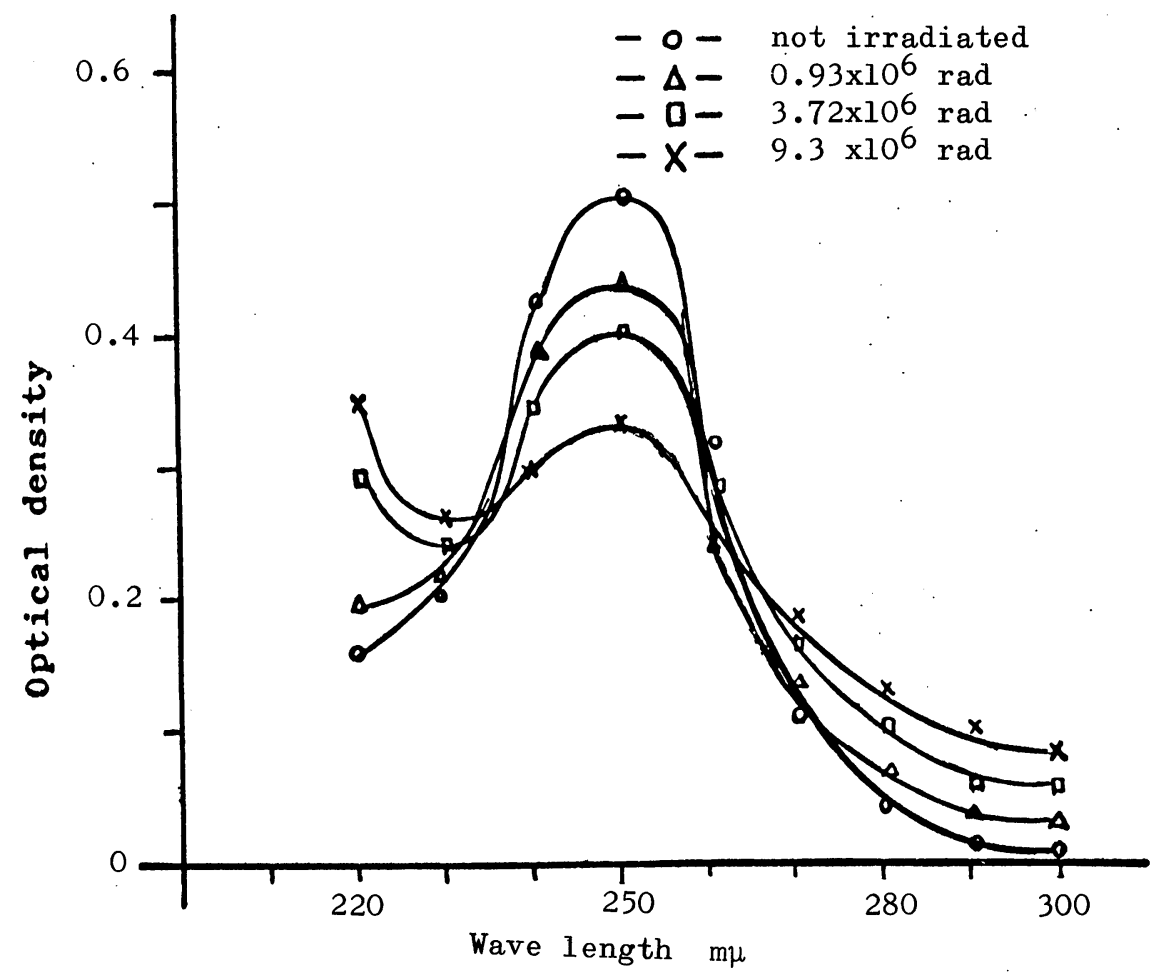

Fig. 2 Change of UV spectra of 5'-IMP irradiated in Tris-buffer ( $\mathrm{pH} 7)$.

Table 3. Comparative stabilities of 5'-nucleotides irradiated in $\operatorname{Tr} i s-b u f f e r(\mathrm{pH} 7)$.

\begin{tabular}{|c|c|c|c|}
\hline \multirow[t]{2}{*}{ 5'-Nucleotides } & \multicolumn{3}{|c|}{$\%$ remaining $5^{\prime}$-nucleotides } \\
\hline & $0.93 \times 10^{6} \mathrm{rad}$ & $4.65 \times 10^{6}$ & $\mathrm{rad}$ \\
\hline $5^{\prime}-$ IMP & 86.9 & 57.4 & \\
\hline $5^{\prime}-\mathrm{GMT}$ & 88.7 & 62.9 & \\
\hline $5^{\prime}-A M P$ & 88.1 & 73.0 & \\
\hline $5^{\prime}-\mathrm{CMP}$ & 83.5 & 53.6 & \\
\hline $5^{\prime}-\mathrm{UMP}$ & 75.0 & 46.9 & \\
\hline
\end{tabular}




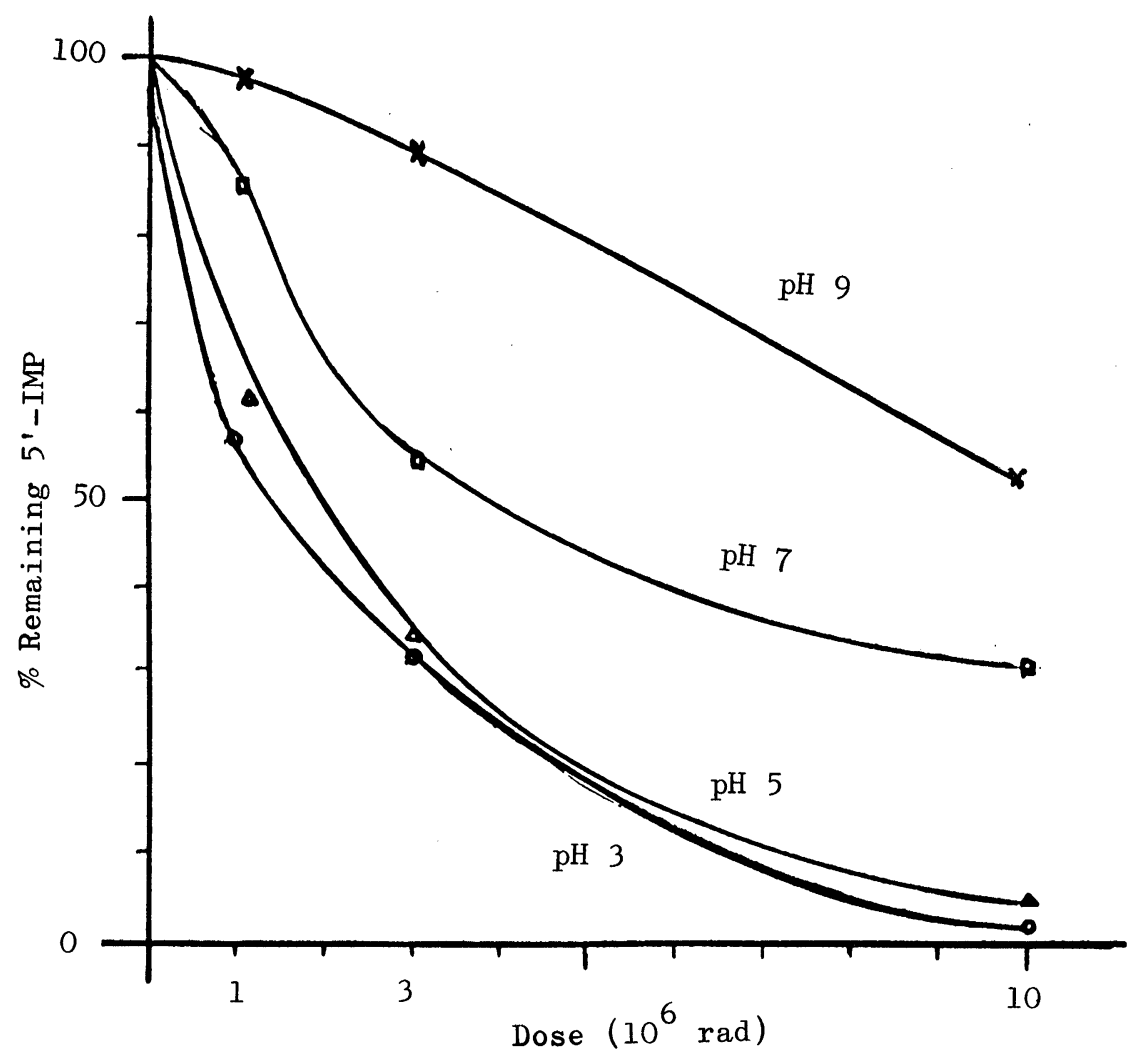

Fig. 3 Stability of $5^{\prime}$-IMP in buffer solutions of various $\mathrm{pH}$.

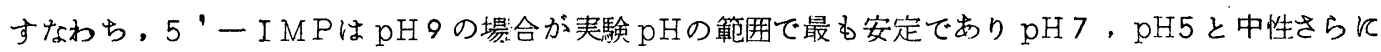
酸性測になるに伴って不安定となった。 pH3と pH 5 との間にはあまり相違はなかった。 IV 個々の5'ーヌクレオチドについて安定性の比較

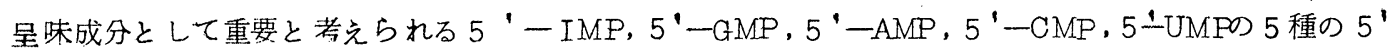
一ヌクレオチド標品の安定性を相互に比較した。すなわらこれらはいずれる単独に $2 \mathrm{mg} / \mathrm{m \ell}$ の濃度になる 上らにトリスBuffer (1/20M, pH 7$)$ 亿溶解し，ガラスアンブル中に空気の共存下に $20 \mathrm{ml}$ 宛封入 してと線を照射した。

線量率は $0.5 \sim 1.0 \times 10^{5} \mathrm{R} / \mathrm{hr}$. 照射線量は $0.93 \times 10^{6} \mathrm{rad}$ と. $65 \times 10^{6} \mathrm{rad} 2$ 種類で あった。結果はTable 3 の上うである。

同表で5'ーヌクレオチドの残存率は $0.93 \times 10^{6}$. rad照射の場合,ブリン系では 87 〜 $8 \%$ 範 囲にありピリミジン系ではUMPが $75 \%$ ，CMPが $84 \%$ でUMPの安定性が低かった。

$4.65 \times 10^{6} \mathrm{rad}$ 照射した場合は低線量のときと同様にプリン采が比較的安定でビリミシン采が不 安定であり $5^{\prime}$-UM Pの安定性が 5 種のヌクレオチドの中で最も低かった。

次にこれら5種の $5^{\prime}$ ーヌクレオチドを混合してて線を照射した。 $\mathrm{pH} 7.0$ のトリ・アミノメタン Bufferk 5'-IMP, $5^{\prime}$-GMP, $5^{\prime}$-AMP, $5^{\prime}$-CMP. $5^{\prime}$-UMPをそれぞれ0. 4 mg/ 100 mlの濃 
度になるように混合して溶解し空気と共にカラスアンブルに封入した。 $5 \times 100^{6} \mathrm{rad}$ 照射したものに ついて未照射のものを対照としてDowex 1 × 8 を用いるカムムクロマトクラフイーによりそのヌクレ オチド組成を比較した。

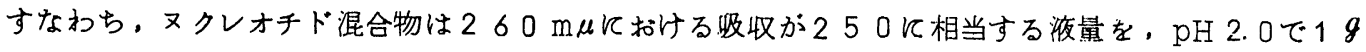
の活性炭柱に吸着させエタノール・アンモニア水で溶出し，溶離液は 40 C C以下で減压濃縮しアンモニ

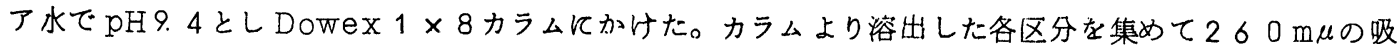
収量を測定し常法によりそれぞれ核酸塩基，又クレオシド,ヌクレオチドとして計算した。結果は $\mathrm{Tab}$ le 4.のようである。

Table 4. Change in the amounts of 5'-nucleotides irradiated in a mixture

\begin{tabular}{|c|c|c|c|c|c|}
\hline $\begin{array}{l}\text { Bases, } \\
\text { Nucleosides }\end{array}$ & $5^{\prime}-\mathrm{CMP}$ & $55^{\prime}-A M P$ & $5^{\prime}-\mathrm{UMP}$ & $55^{\prime}-\mathrm{IMP}$ & $5^{\prime}-\mathrm{GMP}$ \\
\hline \multicolumn{6}{|l|}{ Control, not irradiated } \\
\hline $\begin{array}{l}\text { Absorbancy at } 260 \mathrm{m \mu} \quad 0.17 \\
(0 . \mathrm{D} . / \mathrm{ml})\end{array}$ & & 9.20 & 7.09 & 4.87 & 7.81 \\
\hline$\mu \mathrm{mol} / \mathrm{ml}$ & 0.672 & 0.647 & 0.717 & 0.705 & 0.665 \\
\hline \multicolumn{6}{|l|}{ Irradiated at $5 \times 10^{6} \mathrm{rad}$} \\
\hline $\begin{array}{l}\text { Absorbancy at } 260 \mathrm{~m} \mu \\
(0 . \mathrm{D} . / \mathrm{ml})\end{array}$ & 2.13 & 6.06 & 1.18 & 3.04 & 4.85 \\
\hline$\mu \mathrm{mol} / \mathrm{ml}$ & 0.344 & 0.429 & 0.119 & 0.438 & 0.401 \\
\hline $\begin{array}{l}\% \text { of remaining } \\
5 ' \text {-nucleotides }\end{array}$ & 51.2 & 66.3 & 16.7 & 62.1 & 60.3 \\
\hline
\end{tabular}

すなわち， $5 \times 10^{6} \mathrm{rad}$ 照射によって塩基、ヌクレオシド区分の吸光最增加が認められた。これは 5 種のヌクレオチト・の分解により生成したものと考えられる。照射前後の混合液化当りの個々のヌクレオチ ト是を比較して残存率（\%) を求めると，5 '-AMP，5 '-IMP，5 '-GMPが比較的高く，5 '-CMP か 低く，5 '-UMPは著るしく低かった。5'ーヌクレオチド相互間の安定性を比較すると，個々に照 射した場合同様にプリン采が比較的安定で、ピリミシン采が不安定であると認められた。

$\mathrm{V}$ 安定性江及任寸共存·食品成分の影響

$5^{\prime}$ ーヌクレオチド標品 水溶液の 成分が共存するのでその影響を受けることが考兄られる。本項では $5^{\prime}$ - I M P 蒸留水に約 2 m 竖度に溶解したもの基本之し，クルコースでは1〜 5\%,サッカロースは0.5〜2.5\%，casamino ac id (Difco製ビタミンフリーカゼイン水解物 ）では0.4〜2.0\%, 食程では0.4〜2.0\%の共存 
の下にそれぞれ1 $0^{6} \mathrm{rad}$ 照射した場合の 5'一IMPの残存率をしらべると Fig４４５のようであっ

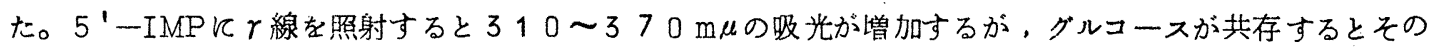
増加が著るしかった。 $\mathrm{pH}$ はサッカロース共存のとき6.0以下に下った。 $5^{\prime}$ - I M P の残存率はクルコー ス1〜 5\%, サッカロース0.5〜2.5\%の共存によって80\%以上となり，これら糖分の共存によって安 定性增すこと，すなわち糖分の保護作用が認められた。casamino acid. 食塩の場合はpHの変化 は6〜7の範囲であった。casamino acid 0.4〜2.0\%の添加によって $5^{\prime}$-IMPの残存率は 80 \%以上となり安定性に対する保護効果が認められた。食塩0.4〜2.0\%の添加に上っては5'一IMPの残 存率には変化はなく保護効果は諗められなかった。

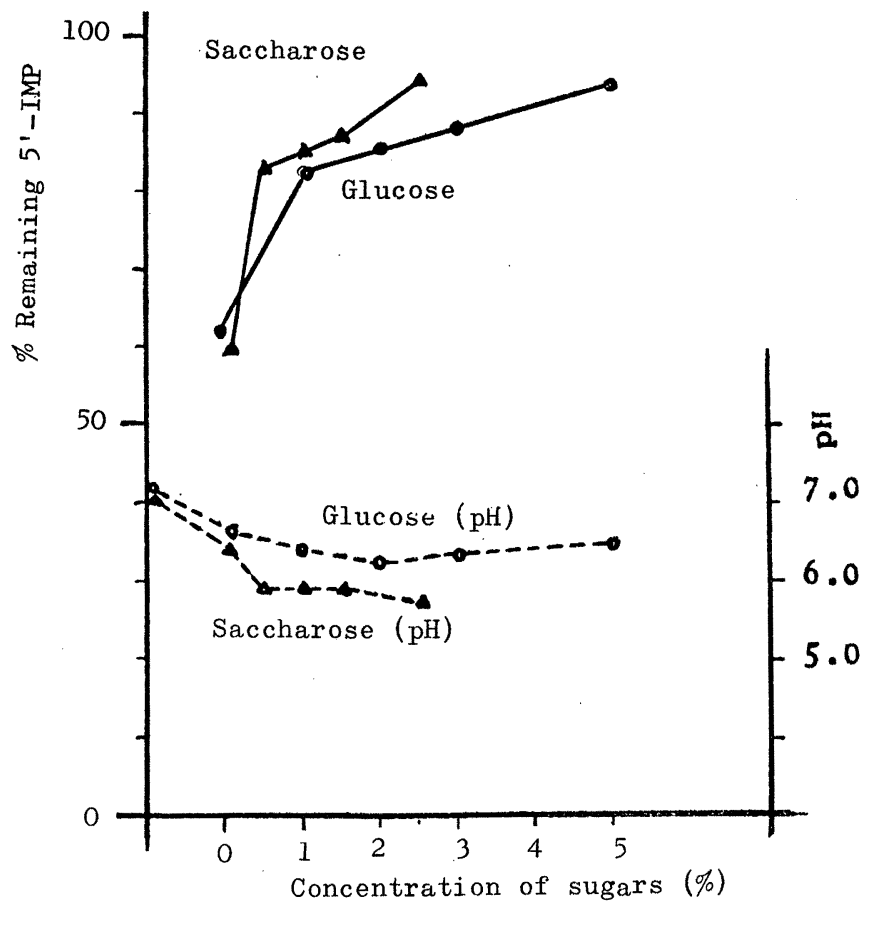

Fig. 4 Stability of 5'-IMP irradiated at $10^{6} \mathrm{rad}$ in the mixture with sugars

以上のように $5^{\prime}$-IMPの安定性は純水溶液上りもトリスBuffer内の方がまた糖分，アミノ酸の共 存によっても增加するのであり，夷際の食品においては種々の糖分，齿白成分など释衝成分を含有するの で， 5'一IMPの安定性は純水溶液に打けるのよりるかなり高いむのであることが推定される。 V5!ーヌクレオチドの分解生成物について

$5^{\prime}$ 一IMP溶液にr線を照射したとき生成する分解物について検討をなった。

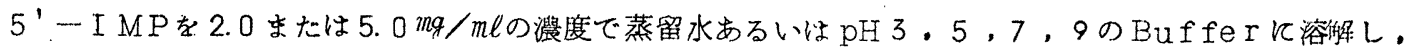

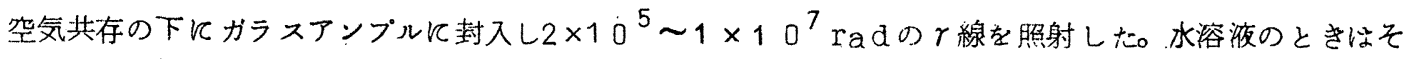

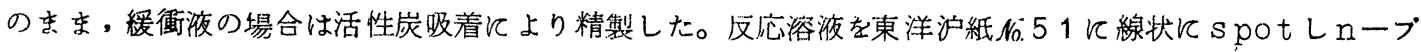




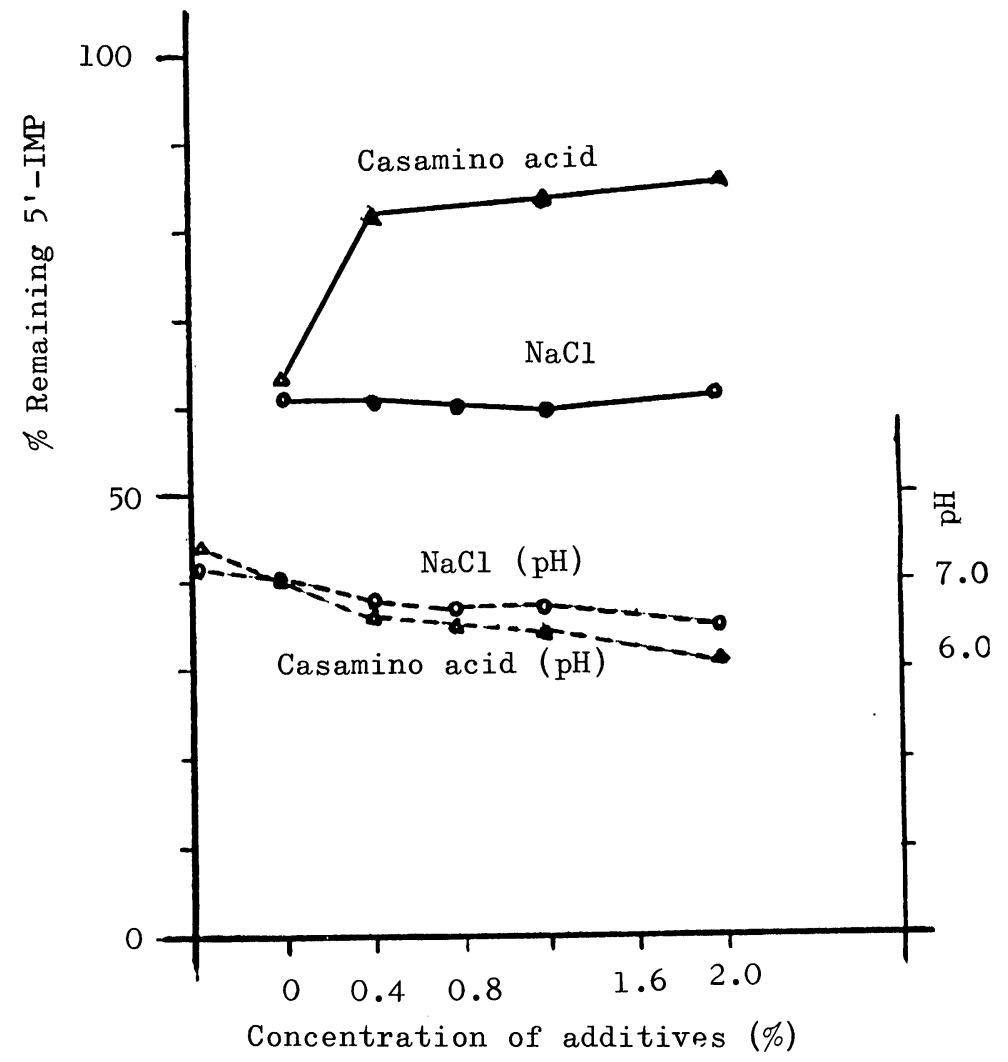

Fig. 5 Stability of 5'-IMP irradiated at $10^{6}$ rad in the mixture with some additives
タノール・酶酸・水( 4 :

$1: 2$ ) あるいは飽和硫安

液・ 1 M酒酸ソーダ液・イン

ープロパール $(80: 20$

:2）を溶媒として展開し 乾品後，紫外部.吸収部分を 切り取って $5 m \ell$ の $0.01 \mathrm{~N}$. $\mathrm{HCl}$ で室温で 2 時間振沮抽 出し, 抽出液について 250 $\mathrm{m} \mu$ の吸収量光電比色計 で測定した。 $5^{\prime}$ - I M P の蒸留水水溶液に照射した 結果はTable 5のようで ある。

すなわち，照射線量の增 加飞伴い $5^{\prime}$ - I MPの残存 率が低下し僅かであるが $250 \mathrm{~m} \mu$ 吸収值も减少し ま大無機燐酸が漸時增加し た。 $250 \mathrm{~m} \mu$ 吸収物質の 内での 5 '-IMP, イノシ ン,ヒポキサンチンの分布

Table 5. Decomposition products of 5'-IMP irradiated with $\gamma$-ray in distilled water

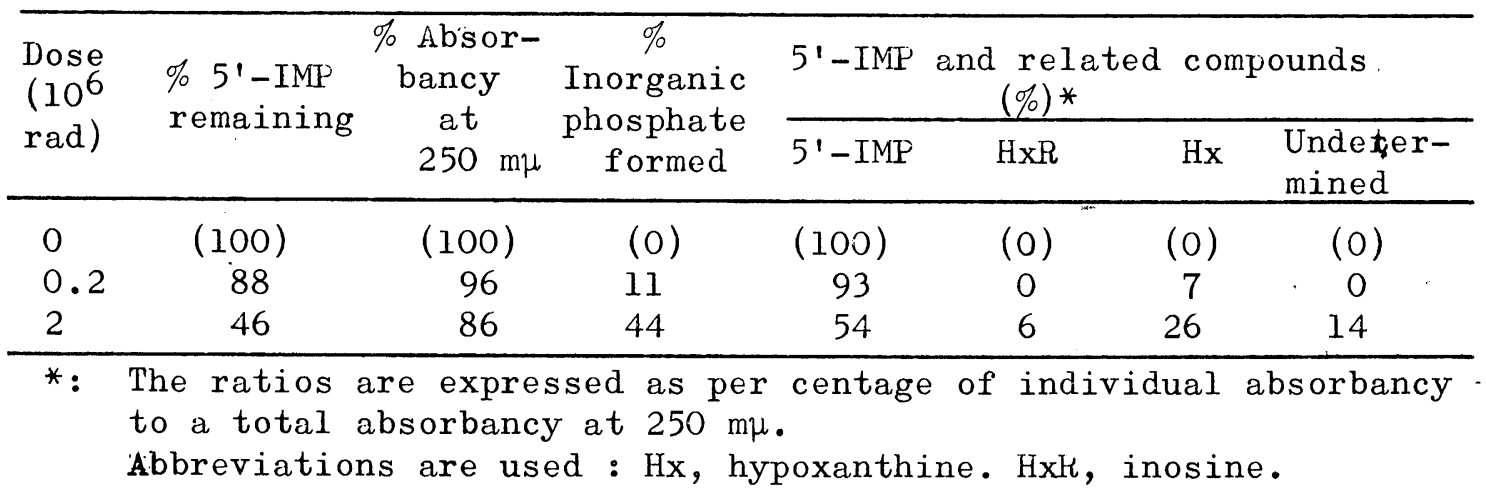


の割合から，5'－IMPが减少するに伴いまずヒポキサンチンが増加するのでイノシン酸の主なる分解 経路としては，塩基部分のヒポキサンチンとリボースとの結合がまず切れて，ヒボキサンチンとリボース 一5一燐酸が生成するが，ほとんど同時に無機燐酸があらわれてくることから，リボースー5一燐酸のリ ボースと燐酸の結合もまた容易に切断される考えられる。な打高線量の場合はイノシンも僅かながら生成 された。

次に $\mathrm{pH}$ 3,5のクエン酸ソーダ・HCl Buffer, pH 7,9のトリスアミノメタン・HCl Buffer 内で 5 'ー I M P r照射して溶液 pHの影響を吟味した。

前項と同様にして分解生成物をベーパークロマトグラフィーで分離したがその一例を示すと Fiｇ．６.の ようである。

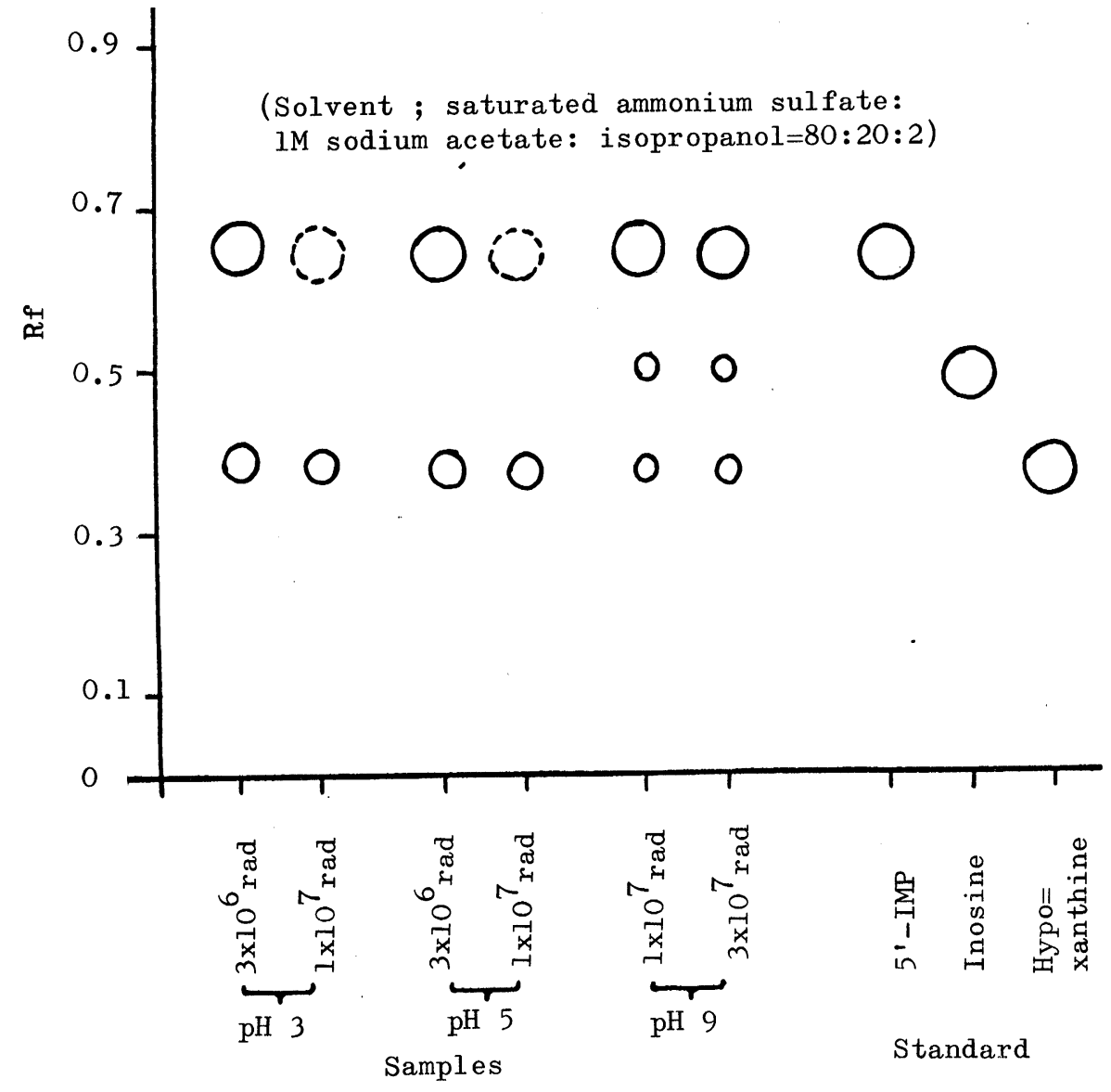

Fig. 6 Chromatogram of the decomposition products of 5'-IMP with $\gamma$-irradiation. 
すなわち，pH3.5では 5 $5^{\prime}$ - I M P 分解によって生成するのは大部分がヒポキサンチンであること，

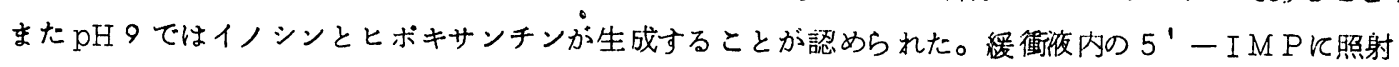
した結果, 分解により生成した $250 \mathrm{~m} \mu$ 吸収物質の分布の割合と無機燐酸の生成. $250 \mathrm{~m} \mu$ 吸収の変 化を示すと Table 6.のよ5である。

Table 6. Decomposition products of 5'-IMP irradiated with $\gamma$-ray in buffer at various $\mathrm{pH}$.

\begin{tabular}{|c|c|c|c|c|c|c|}
\hline \multirow{2}{*}{$\begin{array}{l}\mathrm{pH} \text { of } \\
\text { buffers }\end{array}$} & \multirow{2}{*}{$\begin{array}{l}\text { Dose } \\
\left(10^{6}\right. \\
\text { rad) }\end{array}$} & \multirow{2}{*}{$\begin{array}{c}\% \text { Absor- } \\
\text { bancy } \\
\text { at } \\
250 \mathrm{m \mu}\end{array}$} & \multirow{2}{*}{$\begin{array}{c}\% \\
\text { Inorganic } \\
\text { phosphate } \\
\text { formed }\end{array}$} & \multicolumn{3}{|c|}{$\begin{array}{r}5^{\prime}-\text { IMP and related compounds } \\
(\%)^{*}\end{array}$} \\
\hline & & & & $5^{\prime}-\mathrm{IMP}$ & $\mathrm{HxR}$ & $\mathrm{Hx}$ \\
\hline & 0 & (100) & (0) & (100) & $(0)$ & (0) \\
\hline 3 & 1 & 93 & 7 & 92 & $1-2$ & 6 \\
\hline \multirow[t]{2}{*}{7} & 5 & 95 & 13 & 94 & $1-2$ & 5 \\
\hline & 5 & 95 & 8 & 96 & $1-2$ & 2 \\
\hline \multirow[t]{2}{*}{9} & 10 & 95 & 14 & 85 & 8 & 7 \\
\hline & 30 & 70 & 40 & 69 & 13 & 18 \\
\hline
\end{tabular}

*: The ratios are expressed as the per centage of individual absorbancy to a total absorbancy at $250 \mathrm{~m} \mu$. Abbreviations are used: Hx, hypoxanthine. HxR, inosine.

VIII 加熱殺菌法との比較

食品の殺菌方法として従来から加熱法(午詰殺菌)が広く行なわれている。加熱処理に際してのヌクレ

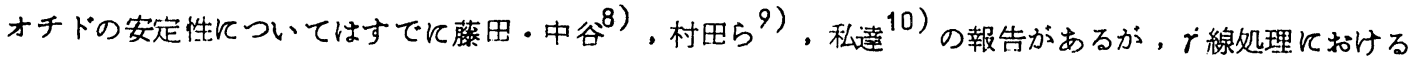
ヌクレオチドの安定性と比較することもまた興味深いと考えられる。すなわちTable 7.に示すようであ ろ。

Table 7. 5'ーヌクレオチドの安定性に対する加熱処理と $r$ 線照射との影響の比較

\section{加熱 の 影 敏}

(1) $100 \%$ 以上になると温度上年に伴い不安定とな る。

(2)中性上り酸性になるに伴い不安定となる。

(3) ピリミシン采又クレオチド即ち 5'ーC M P ， 5 '一UMPが比較的安定で,ブリン采は不安定

(4) ヌクレオチドのリボースと燐酸との結合が先づ切 れてヌタレオシドを生成する。

但し $\mathrm{pH} 2$ 以下では核酸程基とリボースの結合が 切九る。

(5). 共存物質の影響

可溶性澌粉・グルコース,サッカロースの共存に 上り分解が促進された。

食塩・クルタミン酸ソーダ，カゼイン酸分解物は ほとんど安定性に影整はない。

\section{$r$ 線 照射の影瑤}

（1）線量が高くなるに伴い不安定となる。

（2）中性上り酸性になるに伴い不安定となる。

(3）加熱の場合と反対にブリン稂ち5'- IMP $5^{\prime}$ - GMP, $5^{\prime}$-AMPが安定で, ピリミ シン采は不安定。

（4） ヌクレオチドの核酸塩基とリボースとの結合 が先ず切れて核酸塩基を生成する。

但し pH 9 ではヌクレオシドも生成する。

（5）共存物質の影響

グルコース，サッカロースは安定性を增加。

糖質の保護作用が みとめられる。

カせイン酸分解物でる保護作用あり。

食塩は影蠁はない。 
$5^{\prime}$-I MPの水溶液中に淤る安定性については上述の上5であるが，一般食品中では共存成分の保 護作用があるので，完全殺菌線量（ $4.5 \mathrm{Mrad}$ ) ておいてもかなり安定なるのと考えられる。

終りに臨み、終始ご懇切なご指導を賜わっている大阪大学工学部寺本教授业びに多大のご援助を賜わっ ている住友原子力工業侏式会社，武田薬品工業侏式会社の皆様方に放礼申し上げます。

\section{文献}

1) Weiss.J.J : Chemical effects of ionizing radiations on nucleic acid and related compounds.

Progress in Nucleic Acid Research and Molecular Biology 3.103 (1964)

2）石原去：核酸および関連物質に対する紫外線照射の影響：生化学35.753(1936)

3) Shugar,D. : The Nucleic acids II. ( ed. by Chargaff,E., Davidson. J.N $)\left(\begin{array}{llll}1 & 9 & 6 & 0\end{array}\right)$

4) Korableva,N.P. and Metlitskij, L.V.：日本食品照射研究協議会刊行物第10 集( $\left(\begin{array}{llll}1 & 9 & 6 & 7\end{array}\right)$

5) Guardia,E.J. and Dollar,A.M. :J.Food Sci.30.223(1965)

6) Spineli,J.: J.Food $S c i .30,1063(1965)$

7) 久保田・渡辺：日本水産学会誌 $33.769(1967)$

8）藤巴・中谷・木村・石井・佐谷：栄荃と食糧 $18.98(1965)$

9) 栗山・伏崎・村田: 栄盖と食糧 $17.337(1965)$

10）憍田・毛利・青山：午詰時報 43 , (1). 65 (1964) 